\title{
Pilot Neonatal Screening Program for Central Congenital Hypothyroidism: Evidence of Significant Detection
}

\author{
Débora Braslavsky ${ }^{a}$ b Maria Virginia Méndez ${ }^{a} \quad$ Laura Prieto $^{a}$ \\ Ana Keselman $^{b}$ Rosa Enacan ${ }^{a} \quad$ Laura Gruñeiro-Papendieck $^{a} \quad$ Nicolas Jullien $^{c}$ \\ Alexandru Savenau $^{c-f}$ Rachel Reynaud ${ }^{c, g}$ Thierry Brue ${ }^{c-e}$ Ignacio Bergadáa, b \\ Ana Chiesa ${ }^{a, b}$ \\ ${ }^{a}$ Fundación de Endocrinología Infantil, Buenos Aires, Argentina; ${ }^{b}$ Centro de Investigaciones Endocrinológicas \\ "Dr. César Bergadá" (CEDIE), División de Endocrinología, Hospital de Niños Ricardo Gutiérrez, Buenos Aires, \\ Argentina; 'Faculté de Médecine de Marseille, Aix-Marseille Université, Centre de Recherche en Neurobiologie \\ et Neurophysiologie de Marseille (CRN2M), Centre National de la Recherche Scientifique, Marseille, France;

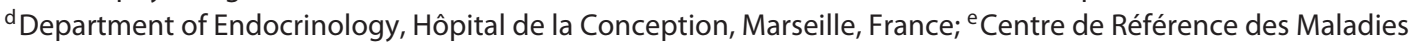 \\ Rares de l'Hypophyse, Hôpital de la Conception, Marseille, France; 'Laboratory of Biochemistry and Molecular \\ Biology, Hôpital de la Conception, Marseille, France; 9 Paediatric Endocrinology Unit, Department of Paediatrics, \\ Assistance Publique - Hôpitaux de Marseille, Marseille, France
}

\section{Keywords}

Central hypothyroidism · Congenital hypothyroidism ·

Congenital hypopituitarism · Neonatal screening program ·

Dried blood specimen

\begin{abstract}
Background/Aim: Congenital hypothyroidism $(\mathrm{CH})$ is a heterogeneous entity. Neonatal screening programs based on thyrotropin (TSH) determination allow primary $\mathrm{CH}$ diagnosis but miss central $\mathrm{CH}(\mathrm{CCH}) . \mathrm{CCH}$ causes morbidity, alerts to other pituitary deficiencies, and is more prevalent than previously thought. We aimed at developing a pilot neonatal screening program for $\mathrm{CCH}$ detection. Patients and Methods: A prospective 2-year pilot neonatal screening study based on simultaneous dried blood specimen TSH and thyroxine $\left(T_{4}\right)$ measurements was implemented in term newborns aged 2-7 days. Those with $\mathrm{T}_{4} \leq 4.5 \mu \mathrm{g} / \mathrm{dL}$ ( -2.3 SDS)
\end{abstract}

and $\mathrm{TSH}<10 \mathrm{mIU} / \mathrm{L}$ were recalled (suspicious of $\mathrm{CCH}$ ) and underwent clinical and biochemical assessment performed by expert pediatric endocrinologists. Results: A total of 67,719 newborns were screened. Primary $\mathrm{CH}$ was confirmed in 24 (1:2,821). Forty-four newborns with potential CCH were recalled (recall rate $0.07 \%$ ) at a mean age of $12.6 \pm 4.8$ days. In this group, permanent CCH was confirmed in 3 (1:22,573), starting $\mathrm{L}^{-\mathrm{T}_{4}}$ treatment at a mean age of $12.3 \pm 6.6$ days; 14 boys showed $T_{4}$-binding globulin deficiency (1:4,837); 24 had transient hypothyroxinemia (21 non-thyroidal illness and 3 healthy); and 3 died before the confirmation stage. According to initial free $\mathrm{T}_{4}$ measurements, $\mathrm{CCH}$ patients had moderate hypothyroidism. Conclusions: Adding $\mathrm{T}_{4}$ to TSH measurements enabled the identification of $\mathrm{CCH}$ as a prevalent condition and contributed to improving the care of newborns with congenital hypopituitarism and recognizing other thyroidal disorders.

(c) 2017 S. Karger AG, Basel

\section{KARGER}

(c) 2017 S. Karger AG, Basel

E-Mail karger@karger.com

www.karger.com/hrp
Débora Braslavsky

Centro de Investigaciones Endocrinológicas “Dr. César Bergadá” (CEDIE)

División de Endocrinología, Hospital de Niños Ricardo Gutiérrez

1330 Gallo Street, Buenos Aires, CABA 1425 (Argentina)

E-Mail dbraslavsky@ cedie.org.ar 


\section{Introduction}

Congenital hypothyroidism $(\mathrm{CH})$ is a heterogeneous entity. At birth, most countries effectively screen for primary $\mathrm{CH}$ by thyrotropin (TSH) determination [1]. However, this approach misses central $\mathrm{CH}(\mathrm{CCH})$, which is caused by disorders of the hypothalamic-hypophyseal system and characterized by impaired TSH production, resulting in low circulating thyroid hormones in combination with low, inappropriately normal, or slightly elevated TSH levels [2]. Although CCH was previously assumed as a rare, mild, and non-relevant disorder, nowadays its spectrum includes an important risk of morbidity, especially when severe cases remain untreated $[3,4]$.

The main underlying cause of $\mathrm{CCH}$ is combined congenital pituitary hormone deficiency (CCPHD), mostly associated with growth hormone (GH) and adrenocorticotropin (ACTH) deficiencies. This may result in recurrent hypoglycemia and acute adrenal insufficiency with impairment of growth and neurodevelopment $[2,5,6]$. Specific symptoms are not usually observed in $\mathrm{CCH}$, and even in those cases where some unspecific clinical findings such as hypoglycemia or cholestasis appear, CCPHD may remain unrecognized during the neonatal period [7].

Different $\mathrm{CCH}$ underlying etiologies have been described lately. These include several monogenic disorders such as mutations in thyroid-stimulating hormone beta subunit $(\beta$-TSH) $[3,8]$, TSH-releasing hormone receptor defects $(T R H-R)$ [9-11], immunoglobulin super family member 1 gene (IGSF1) $[12,13]$, and transducin-like protein $1 \mathrm{X}$-linked (TBLX1) [14]. Each of these has its own clinical and biochemical characteristics, and if no specific study at birth is performed, they are frequently undiagnosed until later [2, 15].

Screening programs that measure thyroxine $\left(\mathrm{T}_{4}\right)$ with reflex TSH in newborns with $\mathrm{T}_{4}$ below a specified cutoff have the potential to detect $\mathrm{CCH}$ and have shown a higher prevalence of $\mathrm{CCH}$ than previously thought, reaching a rate of $1: 16,000$ to $1: 21,600[16,17]$.

Therefore, the aim of this study was to develop a pilot neonatal screening program adding dried blood specimen (DBS) $\mathrm{T}_{4}$ determination to our already-based TSH program to determine the incidence of $\mathrm{CCH}$ and to evaluate the feasibility and benefits of this strategy.

\section{Patients and Methods}

A prospective pilot neonatal screening study based on the simultaneous DBS determination of TSH and total $\mathrm{T}_{4}$ was conducted from June 1, 2014, to June 1, 2016, in term newborns aged be- tween 2 and 7 days of life in the city of Buenos Aires. During the trial period, newborns with $\mathrm{T}_{4} \leq 4.5 \mu \mathrm{g} / \mathrm{dL}(-2.3 \mathrm{SDS})$ associated with $\mathrm{TSH}<10 \mathrm{mIU} / \mathrm{L}$ were suspected of $\mathrm{CCH}$, recalled, and referred to pediatric endocrinologists. All underwent a specific clinical assessment to find $\mathrm{CCH}$ signs or symptoms, including concomitant life-threatening comorbidities such as hypoglycemia, dysnatremia, and cholestasis.

Biochemical confirmation tests included a complete evaluation of the pituitary-thyroid axis (serum $\mathrm{TSH}, \mathrm{T}_{4}$, free $\mathrm{T}_{4}\left[\mathrm{FT}_{4}\right]$, triiodothyronine $\left[\mathrm{T}_{3}\right]$, thyroglobulin, and antithyroid antibodies) as well as additional pituitary function tests (serum cortisol, prolactin, gonadotropins, testosterone, GH, IGF-I, IGFBP-3, electrolytes, glucose, and liver function). Serum $\mathrm{T}_{4}$-binding globulin (TBG) determination was performed in patients likely to suffer from TBG deficiency (low $\mathrm{T}_{4}$ with normal $\mathrm{FT}_{4}$ and TSH concentrations). Maternal thyroid function was evaluated in all cases. In those patients with confirmed diagnosis of permanent $\mathrm{CCH}$, a brain magnetic resonance imaging (MRI) was requested and molecular study of transcription factors involved in pituitary development was initiated. $\mathrm{CH}$ severity was classified according to $\mathrm{FT}_{4}$ level at confirmation stage [18].

\section{Laboratory Methods}

Neonatal DBS TSH was measured by IFMA (Delfia) (intra- and interassay coefficients of variation $[\mathrm{CV}] 7$ and $8 \%$, respectively, for a TSH of $10 \mathrm{mIU} / \mathrm{L}$ ) with a functional sensitivity of $2 \mathrm{mIU} / \mathrm{L}$. $\mathrm{T}_{4}$ was measured by FIA (Delfia) (intra- and interassay CV were 7.1 and $4.1 \%$, respectively, for a $\mathrm{T}_{4}$ of $4.5 \mu \mathrm{g} / \mathrm{dL}$ ) with a functional sensitivity of $1.8 \mu \mathrm{g} / \mathrm{dL}$.

Serum TSH, $\mathrm{T}_{4}, \mathrm{FT}_{4}, \mathrm{~T}_{3}$, thyroglobulin, antithyroid antibodies, cortisol, prolactin, gonadotropins, and testosterone were measured by electrochemiluminescence immunoassay (ECLIA), Cobas e411. GH, IGF-I, and IGFBP-3 were measured by a 2 -site chemiluminescence immunometric assay IMMULITE ${ }^{\circledR} 2000$ system (Siemens Healthcare Diagnostics Products Ltd., Gwynedd, UK). Serum TBG was measured by chemiluminescence.

Genomic analysis of candidate genes (PROP1, POU1F1, LHX4, LHX3, HESX1, PROKR2, OTX2, SOX3) was performed by sequencing in each case according to an adapted screening algorithm [19]. All coding exons and intron region boundaries of these genes were amplified from genomic DNA as previously described using exon-flanking primers (sequence posted online) [20].

\section{Statistics}

Data were expressed as median and range to describe hormone concentrations and as mean and standard deviation score to express age. Prevalence, recall rates (RR), and costs per detected case were calculated. $\mathrm{DBS} \mathrm{T}_{4}$ levels of diagnostic groups were compared by the Mann-Whitney test. Statistical analyses were performed using GraphPad Prism version 5.01 for Windows (GraphPad Software, San Diego, CA, USA). The alpha level was set at 0.05.

\section{Results}

Throughout the study, 67,719 full term newborns were screened by measuring $\mathrm{T}_{4}$ and TSH simultaneously. A flow chart of the results is shown in Figure 1. Primary hy- 
Table 1. Biochemical results of DBS and serum samples at confirmation stage, according to final diagnosis

\begin{tabular}{|c|c|c|c|c|c|c|c|c|}
\hline & $n$ & $\begin{array}{l}\mathrm{TSH}, \\
\mathrm{mIU} / \mathrm{L}\end{array}$ & $\begin{array}{l}\mathrm{T}_{4} \\
\mu \mathrm{g} / \mathrm{dL}\end{array}$ & $\begin{array}{l}\text { TSH, } \\
\mathrm{mIU} / \mathrm{L}\end{array}$ & $\begin{array}{l}\mathrm{T}_{4} \\
\mu \mathrm{g} / \mathrm{dL}\end{array}$ & $\begin{array}{l}\mathrm{FT}_{4}, \\
\mathrm{ng} / \mathrm{dL}\end{array}$ & $\begin{array}{l}\mathrm{T}_{3} \\
\mathrm{ng} / \mathrm{dL}\end{array}$ & $\begin{array}{l}\text { Thyroglobulin, } \\
\text { ng/dL }\end{array}$ \\
\hline $\mathrm{CCH}$ & 3 & $<2.0$ & $3.00(2.5-4.5)$ & $3.79(2.0-7.0)$ & $3.90(2.19-5.15)$ & $0.56(0.48-0.77)$ & $76(56-115)$ & $42.5(11-74)$ \\
\hline НуроТВG & 14 & 2.2 & $2.52(1.4-4.1)$ & $4.86(1.7-10.1)$ & $2.40(1.54-4.30)$ & $1.52(0.67-1.96)$ & $56(43-99)$ & $92.0(60-219)$ \\
\hline NTI & 21 & $<2.0$ & $4.05(2.2-4.5)$ & $3.97(0.58-14.4)$ & $10.5(6.20-20.0)$ & $1.57(1.19-2.08)$ & $169(71-219)$ & $29.4(16-72)$ \\
\hline Reference & & $<10.0$ & $\geq 4.5$ & $1.3-10$ & $6-18$ & $1.0-2.6$ & $105-325$ & $18-145$ \\
\hline
\end{tabular}

Data are presented as median (range). DBS, dried blood specimens; $\mathrm{TSH}$, thyrotropin; $\mathrm{T}_{4}$, thyroxine; $\mathrm{FT}_{4}$, free $\mathrm{T}_{4}$; $\mathrm{T} 3$, triiodothyronine; $\mathrm{CCH}$, central congenital hypothyroidism; HypoTBG, thyroid-binding globulin deficiency; NTI, non-thyroidal illness.

pothyroidism was suspected in 135 newborns (RR 0.20\%) and confirmed in 24 . Forty-four newborns with a potential diagnosis of $\mathrm{CCH}$ were recalled (RR $0.07 \%$ ) at a mean age of $12.6 \pm 4.8$ days. TSH and $\mathrm{T}_{4}$ concentrations are shown in Table 1. At confirmation stage, 21/44 (45\%) were still hospitalized due to different conditions.

Permanent $\mathrm{CCH}$ (median $\mathrm{T}_{4}$ : $3.0 \mu \mathrm{g} / \mathrm{dL}$; Table 1) was confirmed in 3 cases ( 2 boys), representing a prevalence of 1:22,573 term newborns. At the time of recall $(3,6$, and 19 days of life), all of them were hospitalized with unspecific symptoms such as hypernatremia, recurrent hypoglycemia and suspicion of sepsis. Their pituitary assessment established that $\mathrm{CCH}$ was associated with other pituitary hormone deficiencies and with abnormal pituitary findings on MRI (Fig. 2). Molecular studies revealed a sporadic POU1F1 R271W heterozygous mutation in 1 patient with GH, prolactin, and TSH deficiencies. Thyroid ultrasounds and maternal thyroid function were normal in the 3 cases. $\mathrm{L}-\mathrm{T}_{4}$ replacement was started at a mean age of $12.3 \pm 6.6$ days. Despite adequate hormone replacement, 1 of these patients died at 0.8 years due to a hypovolemic shock secondary to severe gastroenteritis. The other $2 \mathrm{CCH}$ patients were followed up and underwent a neurodevelopmental evaluation (Gesell maturity scale) at 1.5 years with a normal developmental global score (DQ) of 84 and 100, respectively (Table 2).

Fourteen apparently healthy boys had TBG deficiency (median $\mathrm{T}_{4}: 2.5 \mu \mathrm{g} / \mathrm{dL}$; Table 1, prevalence 1:4,837 newborns), confirmed upon serum TBG determination (nondetectable levels). Fifty percent of mothers revealed serum TBG below the normal range. In this group, 2 patients without comorbid conditions and absence of hypopituitary features had $\mathrm{FT}_{4}$ levels below the normal range (0.67 and $0.90 \mathrm{ng} / \mathrm{dL}$, respectively), while other pi-

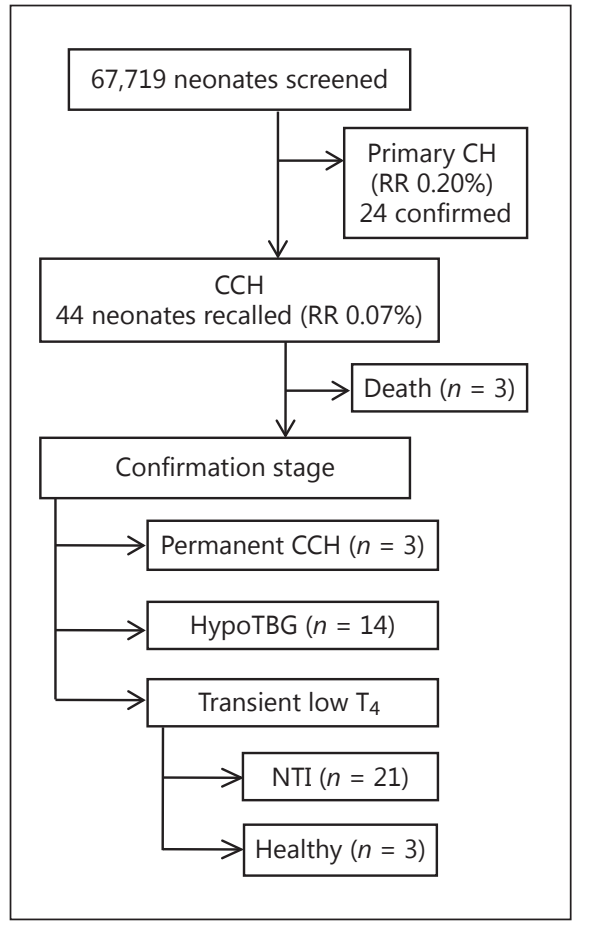

Fig. 1. Overview of simultaneous thyrotropin-thyroxine (TSH-T screening results (flowchart). $\mathrm{CH}$, congenital hypothyroidism; $\mathrm{CCH}$, central $\mathrm{CH}$; $\mathrm{TBG}, \mathrm{T}_{4}$-binding globulin; NTI, non-thyroidal llness.

tuitary axes were unaffected. In both, isolated $\mathrm{CCH}$ was initially assumed, and $\mathrm{L}-\mathrm{T}_{4}$ treatment was initiated with a marked increment of $\mathrm{FT}_{4}$ without $\mathrm{T}_{4}$ changes and suppressed TSH. A non-detectable TBG level led to $\mathrm{L}_{-} \mathrm{T}_{4}$ discontinuation at 14 and 3 months, respectively, and thereafter they displayed a typical TBG deficiency pattern (normal $\mathrm{FT}_{4}$, low $\mathrm{T}_{4}$, and normal TSH). 

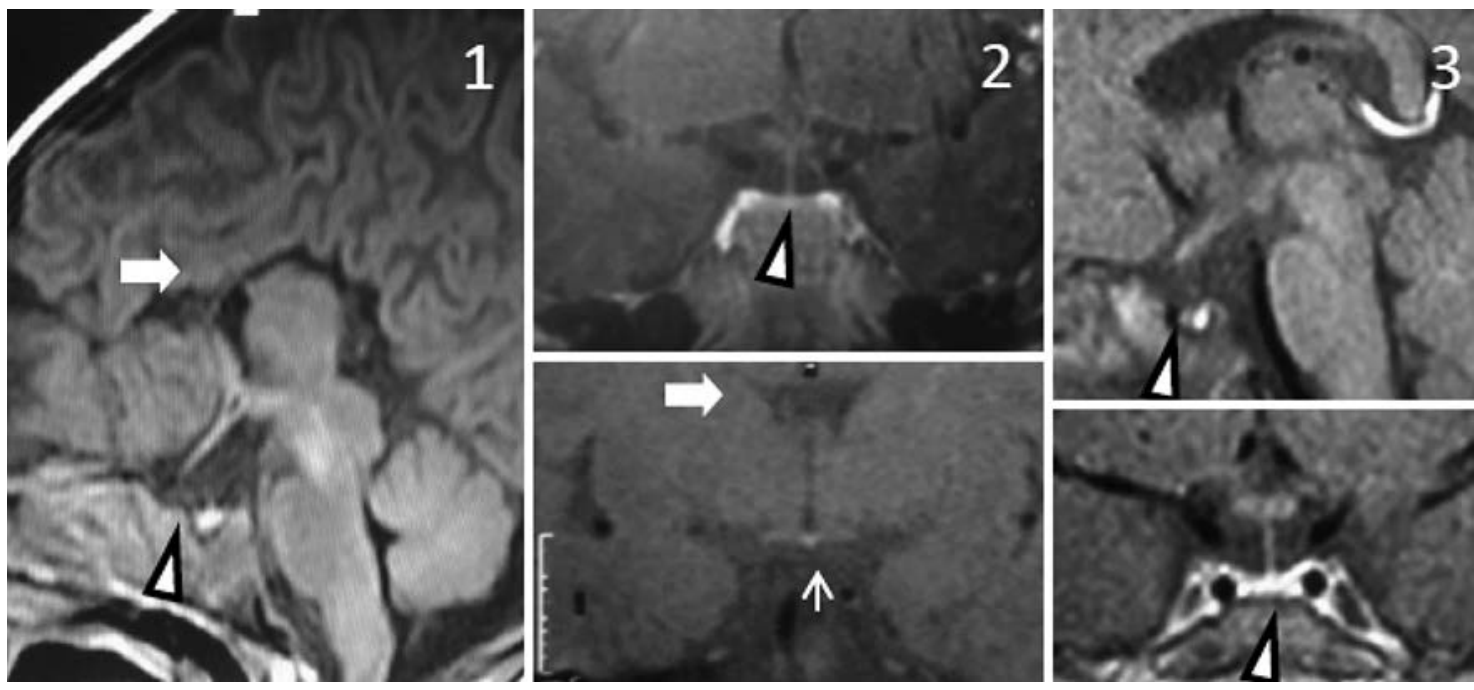

Fig. 2. Brain MRI of the 3 patients with detected central congenital hypothyroidism. Thick arrows show midline defects: corpus callosum agenesia (image 1) and absence of septum pellucidum (image 2); arrowheads: anterior pituitary hypoplasia (images $1-3$ ); thin arrow: ectopic neurohypophysis.

Table 2. Details of newborns with permanent central congenital hypothyroidism

\begin{tabular}{|c|c|c|c|c|c|c|c|c|c|c|c|c|c|}
\hline & \multicolumn{2}{|c|}{ Filter paper } & \multicolumn{5}{|c|}{ Serum samples } & \multirow[t]{2}{*}{ Gender } & \multirow{2}{*}{$\begin{array}{l}\text { Hormone } \\
\text { deficiencies }\end{array}$} & \multirow[t]{2}{*}{ Brain MRI } & \multirow{2}{*}{$\begin{array}{l}\text { Molecular } \\
\text { studies }\end{array}$} & \multirow{2}{*}{$\begin{array}{l}\text { Hormone } \\
\text { replace- } \\
\text { ment, days }\end{array}$} & \multirow{2}{*}{$\begin{array}{l}\text { Follow- } \\
\text { up, years }\end{array}$} \\
\hline & $\begin{array}{l}\text { TSH, } \\
\mathrm{mIU} / \mathrm{L}\end{array}$ & $\begin{array}{l}\mathrm{T}_{4}, \\
\mu \mathrm{g} / \mathrm{dL}\end{array}$ & $\begin{array}{l}\text { TSH, } \\
\mathrm{mIU} / \mathrm{L}\end{array}$ & $\begin{array}{l}\mathrm{T}_{4}, \\
\mu \mathrm{g} / \mathrm{dL}\end{array}$ & $\begin{array}{l}\mathrm{FT}_{4}, \\
\mathrm{ng} / \mathrm{dL}\end{array}$ & $\begin{array}{l}\mathrm{T}_{3} \\
\mathrm{ng} / \mathrm{dL}\end{array}$ & $\begin{array}{l}\mathrm{Tg}, \\
\mathrm{ng} / \mathrm{dL}\end{array}$ & & & & & & \\
\hline 1 & $<2.0$ & 3.00 & 7.07 & 2.19 & 0.48 & 56 & 11 & M & $\begin{array}{l}\text { TSH, ACTH, } \\
\text { ADH }\end{array}$ & $\begin{array}{l}\text { APH, midline } \\
\text { defects }\end{array}$ & $\begin{array}{l}\text { LHX } 4^{\mathrm{w} / \mathrm{w}} \\
H E S X 1^{\mathrm{w} / \mathrm{w}}\end{array}$ & 8 & Died 0.8 \\
\hline 2 & $<2.0$ & 2.50 & 3.79 & 5.15 & 0.77 & 115 & - & M & $\begin{array}{l}\text { TSH, ACTH, } \\
\text { GH }\end{array}$ & $\begin{array}{l}\text { APH, ENH, } \\
\text { midline defects }\end{array}$ & $\begin{array}{l}\text { LHX } 4^{\mathrm{w} / \mathrm{w}} \\
H E S X 1^{\mathrm{w} / \mathrm{w}}\end{array}$ & 20 & 2.5 \\
\hline \multirow[t]{2}{*}{3} & $<2.0$ & 4.5 & 2.00 & 3.90 & 0.59 & 76 & 74 & $\mathrm{~F}$ & \multirow{2}{*}{\multicolumn{2}{|c|}{ TSH, GH, PRL APH }} & $\begin{array}{l}P O U 1 F 1^{\mathrm{w} / \mathrm{m}} \\
R 271 \mathrm{~W}, \\
\text { de novo }\end{array}$ & 9 & 2.2 \\
\hline & $2-10$ & $>4.5$ & $1.3-10$ & $6-18$ & $1.0-2.6$ & $105-325$ & $18-145$ & & & & & & \\
\hline
\end{tabular}

Thyroid profile at screening and confirmation stages, further pituitary assessment, and follow-up. Tg, thyroglobulin; APH, anterior pituitary hypoplasia; ENH, ectopic neurohypophysis. See Table 1 footnote for other abbreviations.

Twenty-four newborns had transient hypothyroxinemia (median $\mathrm{T}_{4}: 4.15 \mu \mathrm{g} / \mathrm{dL}$; Table 1). Twenty-one of them were severely ill at the time of screening and were assumed as having non-thyroidal illness (NTI). Most of those screened were being hospitalized for respiratory distress or sepsis, 1 had a urinary tract infection, and 1 had an isolated transient ACTH deficiency. At confirmation stage, all were markedly or completely recovered with a concomitant increment in their $\mathrm{T}_{4}$ serum levels. Three of these patients evolved with transient hyperthyrotropinemia (maximum TSH of $14.0 \mathrm{mIU} / \mathrm{L}$ ), which lasted up to 5 months in 1 patient. One boy first diagnosed with NTI was diagnosed TBG deficiency after overcoming his illness. The remaining 3 neonates with transient hypothyroxinemia were healthy without any known pathological background.

Three newborns who had abnormal $\mathrm{T}_{4}$ levels on DBS died within the first 2 weeks of life (1 was polymalformated, 1 had complex congenital heart disease, and 1 suffered cardiopulmonary arrest). No confirmation studies were available, and no signs suggestive of $\mathrm{CCH}$ were recovered. 


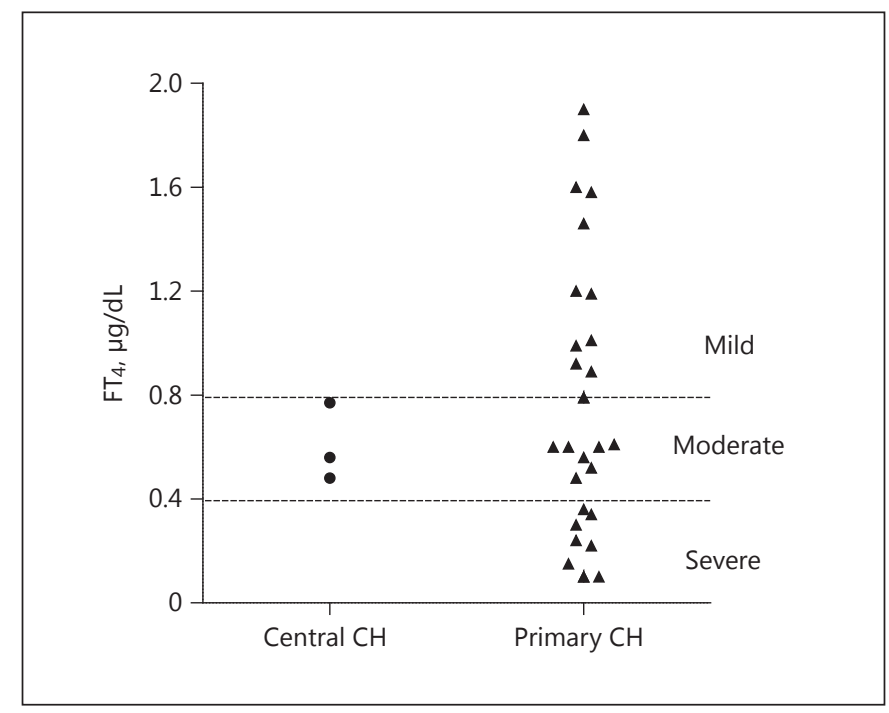

Fig. 3. Severity of $\mathrm{FT}_{4}$ levels at confirmation stage in central $\mathrm{CH}$ and primary $\mathrm{CH}$ [18]. $\mathrm{CH}$ : congenital hypothyroidism; $\mathrm{FT}_{4}$, free thyroxine.

The $\mathrm{T}_{4}$ screened levels in permanent $\mathrm{CCH}$ were not significantly different to either transient hypothyroxinemia $(p=0.39)$ or hypoTBGemia $(p=0.26)$. $\mathrm{T}_{4}$ was significantly lower in the hypoTBG group compared to transient hypothyroxinemia $(p<0.001)$ (Table 1). TSH concentrations (DBS screening) were mostly non-detectable in transient $\mathrm{CCH}$ patients and in half of the newborns with TBG deficiency (Table 1).

Based on initial serum $\mathrm{FT}_{4}$ concentrations, hypothyroidism in primary $\mathrm{CH}$ patients (mean age of $13.3 \pm 4.8$ days) was severe in 9/24 (37.5\%), moderate in $7 / 24(29 \%)$, and mild in $8 / 24(33.5 \%)$, while in all $3 \mathrm{CCH}$ patients, $\mathrm{FT}_{4}$ concentrations were in a moderate range (mean age of 9.3 \pm 6.9 days) (Fig. 3 ).

The cost of the TSH-based strategy for primary $\mathrm{CH}$ detection was USD 106,996/2 years, meaning USD 4,458 per each detected case. Adding DBS $\mathrm{T}_{4}$ determination generated an extra cost of USD 2.2 for every screened newborn. Thus, the simultaneous $\mathrm{TSH}-\mathrm{T}_{4}$ determination strategy increased the costs to USD $148,982 / 2$ years, equaling USD 49,661 per each detected CCH patient.

\section{Discussion}

Neonatal screening programs are an invaluable public health tool. Created to detect certain congenital diseases, they aim at modifying their deleterious natural course.

Neonatal Screening Program for Central

Hypothyroidism
They started in the early 1960s and progressively expanded with new determinations to accurately identify and treat metabolic, neurological, and endocrine diseases. Nevertheless, their use in the approach to new diseases should be based on updated information on the disorder, its prevalence, natural course if undetected, available tools for detection, and treatment and cost benefits. [21]. $\mathrm{CCH}$ encompasses a group of rare diseases that frequently remains unrecognized during the neonatal period.

In our country and for the last 30 years, the detection of primary $\mathrm{CH}$ has been TSH based and has shown good cost-effectiveness. Therefore, in order to detect $\mathrm{CCH}$ patients, we undertook this pilot study, adding $\mathrm{T}_{4}$ to our ongoing TSH-based program during the study period.

This pilot study reveals a relatively high prevalence of $\mathrm{CCH}(1: 22,573)$, similar to that reported by other studies $[16,17]$. In addition, it accounts for $11 \%$ of all detected cases of permanent $\mathrm{CH}$. As expected, all the patients with $\mathrm{CCH}$ had CCPHD [2]. Only 1 patient exhibited clinical findings that could have suggested a pituitary disorder. The remaining 2 patients did not show a classical phenotype, thus avoiding an early diagnosis as usually occurs with congenital hypopituitarism. It is important to highlight that our patients were diagnosed at an earlier age compared to reported cohorts of congenital hypopituitarism $[6,22,23]$.

The implementation of this pilot screening program focused on 2 specific aspects: establishing the $\mathrm{T}_{4}$ cutoff levels and the relevant role of experienced specialists at the stage of confirmation. $\mathrm{CCH}$ may be progressive, and some newborns may only show a moderate decrease in serum $\mathrm{T}_{4}$ concentrations overlapping normal values. This should be assumed as part of the natural course and severity of the disease rather than a false-negative result of the screening. We studied the normal distribution of $\mathrm{T}_{4}$ on DBS. Since we did not know in advance the work-up needed to confirm the recalled babies, we choose a $\mathrm{T}_{4}$ value of -2.3 SDS for a recall level of maximal alert. This strategy requires the clinical skills not only to suspect $\mathrm{CCH}$ but also to rule out conditions involving transient central hypothyroidism such as prematurity, born to hyperthyroid mothers, certain drug treatments that suppress the thyroid axis, and NTI. In addition, the search for comorbidities related to CCPHD urges a specific workup to prevent potential sequelae.

The prevalence of TBG deficiency found in our study was relatively high, similar to that previously reported using DBS or serum neonatal TBG $[24,25]$. The unavail- 
ability of routine DBS TBG determination in our screening increased the RR in $43 \%$. If available, their work-up would have stopped sooner. Nevertheless, we think these families benefited from this finding as it is usually misinterpreted, leading to erroneous $\mathrm{L}-\mathrm{T}_{4}$ replacement. As described above, TBG deficiency was diagnosed in 2 patients with low $\mathrm{FT}_{4}$ levels, thus making it difficult to differentiate them from isolated $\mathrm{CCH}$ [17]. It is difficult to assess whether they have benefited from transient $\mathrm{L}_{-} \mathrm{T}_{4}$ treatment.

NTI constituted our major cause of recall, similar to other $\mathrm{CCH}$ programs. Regarding the 3 neonates who died before the confirmation stage, although they probably suffered NTI, their serum thyroid profile was not available to confirm it.

It has been described that up to $14.5 \%$ of recalled babies may have low $\mathrm{T}_{4}$ without an obvious explanation [16]. In our study, 7\% of newborns recalled with probable $\mathrm{CCH}$ appeared healthy with no previous pathological conditions known. This figure might vary according to the $\mathrm{T}_{4}$ cutoff used in each screening program.

The precise clinical impact of TSH deficiency is difficult to ascertain. However, the relevance of this entity is highlighted by the fact that serum $\mathrm{T}_{4}$ concentrations in $\mathrm{CCH}$ did not statistically differ from the levels found in primary $\mathrm{CH}[18,26]$. In this study, initial $\mathrm{FT}_{4}$ in $\mathrm{CCH}$ newborns were in the range of moderate severity according to the categories previously established for primary $\mathrm{CH}$ [18]. Comparing the magnitude of hypothyroidism in patients with $\mathrm{CCH}$ and that in the cohort of patients with detected primary $\mathrm{CH}$, we have determined that $\mathrm{FT}_{4}$ serum levels of CPHD do not significantly differ from eutopic or ectopic primary hypothyroidism. Even though no patients with $\beta$-TSH deficiency were detected in our study, it is well known that they have severely low $\mathrm{FT}_{4}$ levels, similar to athyreotic patients $[3,8]$. Our experience corroborates that, although thyroid impairment might not be so severe, a prompt diagnosis of $\mathrm{CCH}$ allows a timely study of other pituitary hormone deficiencies and associated comorbidities.

According to our results, neonatal screening for $\mathrm{CCH}$ fulfills the criteria for disease screening regarding its prevalence, confirmation, and treatment as much as other less prevalent metabolic disorders currently included in many screening programs. To further recommend this strategy, we should optimize its cost-effectiveness, studying larger cohorts and expanding the search for milder forms.

\section{Conclusions}

Neonatal $\mathrm{T}_{4}$ determination allows the identification of $\mathrm{CCH}$ as a prevalent condition. Although no studies support that $\mathrm{CCH}$ screening is better for detection than clinical presentation, it may improve morbidity and reduce mortality because of unrecognized diagnosis.

We believe that the neonatal screening program based on TSH and $\mathrm{T}_{4}$ contributes to improving the care of newborns with congenital hypopituitarism and some other hypothalamic-pituitary-thyroidal disorders. Noteworthy, as it fulfils the criteria for disease screening, introducing it into current neonatal screening programs should be considered.

\section{Acknowledgments}

We are grateful to M.G. Ballerini and Maria Eugenia Rodriguez for their biochemical assessment at the confirmation stage, to A.M. Montese, M. Campos, and S. Gonzalez for their technical assistance, and to the nursing staff of the Endocrinology Unit of Hospital Dr. Ricardo Gutiérrez for their cooperation. We acknowledge Dr. S. Bengolea, who participated in the follow-up of $1 \mathrm{CCH}$ patient and Drs. A. Tangari and A. Forrester for their helpful initial assistance with recalled patients. D.B. was the recipient of a scholarship from the Fundación de Endocrinología Infantil (FEI). I.B. and A.C. are researchers from the Health Research Council of the Government of the City of Buenos Aires.

\section{Statement of Ethics}

This study was approved by the local Ethics Committee. Consent for adding $\mathrm{T}_{4}$ measurement to the current DBS neonatal sample in order to expand the causes of $\mathrm{CH}$ was obtained from every maternity ward.

\section{Disclosure Statement}

The authors declare no conflicts of interest.

\footnotetext{
References $>1$ Chiesa A, Prieto L, Mendez V, Papendieck P, Calcagno M de L, Gruñeiro-Papendieck L: Prevalence and etiology of congenital hypothyroidism detected through an Argentine neonatal screening program (1997-2010). Horm Res Paediatr 2013;80:185-192.

-2 Schoenmakers N, Alatzoglou KS, Chatterjee VK, Dattani MT: Recent advances in central congenital hypothyroidism. J Endocrinol 2015;227:R51-R71.
}

Braslavsky et al. 
-3 Domené HM, Gruñeiro-Papendieck L, Chiesa A, Iorcansky S, Herzovich VC, Papazian R, Forclaz V, Prieto L, Sansó G, Scaglia P, Bre M, Chamoux A, Heinrich JJ: The C105fs114X is the prevalent thyrotropin beta-subunit gene mutation in Argentinean patients with congenital central hypothyroidism. Horm Res 2004;61:41-46.

4 Grüters A, Biebermann H, Krude H: Neonatal thyroid disorders. Horm Res 2003;59(suppl 1):24-29.

5 Blizzard RM, Alberts M: Hypopituitarism, hypoadrenalism, and hypogonadism in the newborn infant. J Pediatr 1956;48:782-792.

-6 Braslavsky D, Keselman A, Galoppo M, Lezama C, Chiesa A, Galoppo C, Bergadá I: Neonatal cholestasis in congenital pituitary hormone deficiency and isolated hypocortisolism: characterization of liver dysfunction and follow-up. Arq Bras Endocrinol Metabol 2011;55:622-627.

-7 Braslavsky D, Keselman A, Chiesa A, Bergadá I: Diagnóstico de endocrinopatía congenital en neonates con ictericia prolongada e hipoglucemia. An Pediatr (Barc) 2012;76:120126.

8 Nicholas AK, Jaleel S, Lyons G, Schoenmakers E, Dattani MT, Crowne E, Bernhard B, Kirk J, Roche EF, Chatterjee VK, Schoenmakers N: Molecular spectrum of TSH $\beta$ subunit gene defects in central hypothyroidism in the UK and Ireland. Clin Endocrinol (Oxf) 2017;86: 410-418.

-9 Collu R, Tang J, Castagné J, Lagacé G, Masson N, Huot C, Deal C, Delvin E, Faccenda E, Eidne KA, Van Vliet G: A novel mechanism for isolated central hypothyroidism: inactivating mutations in the thyrotropin-releasing hormone receptor gene. J Clin Endocrinol Metab 1997;82:1561-1565.

10 Bonomi M, Busnelli M, Beck-Peccoz P, Costanzo D, Antonica F, Dolci C, Pilotta A, Buzi F, Persani L: A family with complete resistance to thyrotropin-releasing hormone. $\mathrm{N}$ Engl J Med 2009;360:731-734.
11 Koulouri O, Nicholas AK, Schoenmakers E, Mokrosinski J, Lane F, Cole T, Kirk J, Farooqi IS, Chatterjee VK, Gurnell M, Schoenmakers $\mathrm{N}$ : A novel thyrotropin-releasing hormone receptor missense mutation (P81R) in central congenital hypothyroidism. J Clin Endocrinol Metab 2016;101:847-851.

12 Joustra SD, van Trotsenburg AS, Sun Y, Losekoot M, Bernard DJ, Biermasz NR, Oostdijk W, Wit JM: IGSF1 deficiency syndrome: a newly uncovered endocrinopathy. Rare Dis 2013;1:e24883.

13 Joustra SD, Heinen CA, Schoenmakers N, Bonomi M, Ballieux BE, Turgeon MO, Bernard DJ, Fliers E, van Trotsenburg AS, Losekoot M, Persani L, Wit JM, Biermasz NR, Pereira AM, Oostdijk W; IGSF1 Clinical Care Group: IGSF1 deficiency: lessons from an extensive case series and recommendations for clinical management. J Clin Endocrinol Metab 2016;101:1627-1636.

14 Heinen CA, Losekoot M, Sun Y, Watson PJ, Fairall L, Joustra SD, Zwaveling-Soonawala N, Oostdijk W, van den Akker EL, Alders M, Santen GW, van Rijn RR, Dreschler WA, Surovtseva OV, Biermasz NR, Hennekam RC, Wit JM, Schwabe JW, Boelen A, Fliers E, van Trotsenburg AS: Mutations in TBL1X are associated with central hypothyroidism. J Clin Endocrinol Metab 2016;101:4564-4573.

15 García M, Fernández A, Moreno JC: Central hypothyroidism in children. Endocr Dev 2014;26:79-107.

16 van Tijn DA, de Vijlder JJ, Verbeeten B Jr, Verkerk PH, Vulsma T: Neonatal detection of congenital hypothyroidism of central origin. J Clin Endocrinol Metab 2005;90:3350-3359.

17 Verkerk PH, van Trotsenburg AS, HoorwegNijman JJ, Oostdijk W, van Tijn DA, Kempers MJ, van den Akker EL, Loeber JG, Elvers LH, Vulsma T: Neonatal screening for congenital hypothyroidism: more than 30 years of experience in the Netherlands (in Dutch). Ned Tijdschr Geneeskd 2014;158:A6564.

18 Léger J, Olivieri A, Donaldson M, Torresani T, Krude H, van Vliet G, Polak M, Butler G; ESPE-PES-SLEP-JSPE-APEG-APPES-ISPAE; Congenital Hypothyroidism Consensus Conference Group: European Society for Paediatric Endocrinology consensus guidelines on screening, diagnosis, and management of congenital hypothyroidism. J Clin Endocrinol Metab 2014;99:363-384.
19 Reynaud R, Gueydan M, Saveanu A, ValletteKasic S, Enjalbert A, Brue T, Barlier A: Genetic screening of combined pituitary hormone deficiency: experience in 195 patients. J Clin Endocrinol Metab 2006;9:3329-3336.

20 Reynaud R, Albarel F, Saveanu A, Kaffel N, Castinetti F, Lecomte P, Brauner R, Simonin G, Gaudart J, Carmona E, Enjalbert A, Barlier A, Brue T: Pituitary stalk interruption syndrome in 83 patients: novel HESX1 mutation and severe hormonal prognosis in malformative forms. Eur J Endocrinol 2011;164:457465

21 Wilson JMG, Jungner G: Principles and Practice of Screening for Disease. Public Health Papers No 34. Geneva, World Health Organization, 1968

22 Ellaway CJ, Silinik M, Cowell CT, Gaskin KJ, Kamath KR, Dorney S, Donaghue KC: Cholestatic jaundice and congenital hypopituitarism. J Paediatr Child Health 1995;31:51-53.

23 Binder G, Martin DD, Kanther I, Schwarze $\mathrm{CP}$, Ranke MB: The course of neonatal cholestasis in congenital combined pituitary hormone deficiency. J Pediatr Endocrinol Metab 2007;20:695-702.

24 Kempers MJ, Lanting CI, van Heijst AF, van Trotsenburg AS, Wiedijk BM, de Vijlder JJ, Vulsma T: Neonatal screening for congenital hypothyroidism based on thyroxine, thyrotropin, and thyroxine-binding globulin measurement: potentials and pitfalls. J Clin Endocrinol Metab 2006;91:3370-3376.

25 Carta Sorcini M, Moschini L, Fiore L, Tomarchio S, Di Iorio MG, Gilardi E, Romagnoli C, Curro V, Carta S: Familial thyroxine-binding globulin deficiency detected in a pilot screening program for congenital hypothyroidism. J Endocrinol Invest 1982;5:21-25.

26 Zwaveling-Soonawala N, van Trotsenburg AS, Verkerk PH: The severity of congenital hypothyroidism of central origin should not be underestimated. J Clin Endocrinol Metab 2015;100:E297-E300. 